\title{
SPECIATION IN THE FISHES OF THE GENUS MENIDIA
}

\author{
William A. Gosline \\ Muscum of Zoology, University of Michigan x
}

Received June 20, 1948

The genus Menidia, which includes the common silversides of the Atlantic and Gulf coasts of the United States, presents several aspects of interest for an evolutionary study. Members of this genus have repeatedly entered fresh water from the sea :-two full species, $M$. audens and $M$. extensa, have evolved from such invasions, and there are rather numerous examples of less-marked fresh-water differentiation within $M$. beryllina. Two species, $M$. beryllina and $M$. menidia. occur together along the Atlantic coast from Massachusetts to Florida, thus permitting a comparative analysis of geographic gradients. Furthermore, these same two species hybridize in Florida. Thus, all gradations from incipient speciation to full specific differentiation, with and without hybridization, are founcl.

According to the most recent treatment (Schultz, 1948), there are only four species in Menidia; it is these four that are dealt with here. $M$. menidia is a saltwater form ranging from Nova Scotia to Florida. M. bery'llina occurs in salt, brackish, and coastwise fresh water from Massachusetts to Vera Cruz, Mexico. $M$. audens is found in fresh water in the lower Mississippi Valley, and M. e.tensa is confined to Lake Waccamaw, a faunistically isolated lake in North Carolina (Hubbs and Raney, 1946). The data to be presented here are focused on $M$. beryllina, for the stock of this species seems to have given rise to $M$. audens and $M$. extensa in one direction and hybridizes with $M$. menidia in another.

The chief characters which have been used in differentiating the forms of the

1 Present address: Dept. of Zool. and Entomology, University of Hawaii, Honolulu, Hawaii.

Evolutiox 2: 306-313. December, 1948. genus are the numbers of anal rays ${ }^{2}$ and of vertebrae, the number and degree of development of the scales, the shape of the mouth and snout, the position of the first clorsal fin, the depth of the body, and the location of the posterior extrenity of the air bladder.

For a study of geographic variation in $M$. beryllina, various of the characters mentioned above may be used. Those which lend themselves most readily to statistical analysis, however, are the numbers of second dorsal and of anal rays (table 1 and figure 1). Within each of the populations examined (with one exception), these two counts are positively correlated (table 1). However, between poptulations there is no correlation between these characters (a correlation coefficient calculated between six representative populations gave +0.04 ). Apparently some factor associated with geography affects one but not the other of these counts between localities, without disturbing the inherent correlation between these characters at any one locality. If, for marine populations, the average second clorsal counts are plotted against latitude (fig. 2), an increase in dorsal ray count is found

2 The methods of making the counts and measurements used in this paper are as follows. The first full-length ray is considered the first ray in the anal and second dorsal, and the last, more or less double, ray is counted as a single ray. The predorsal scale count includes as $\mathrm{c} x$ tremities the first scale behind the dark area of the head and the last normally shaped predorsal scale. The preventral count includes all scales in the midline from the istlimus to the posteriormost scale between the ventral fins. The total scale count is taken along that series which runs just above the pectoral base. The depth of body is measured at the level of the anus. Vertebral counts include the urostyle; the first caudal vertebra is that with the first closed haemal arch. 


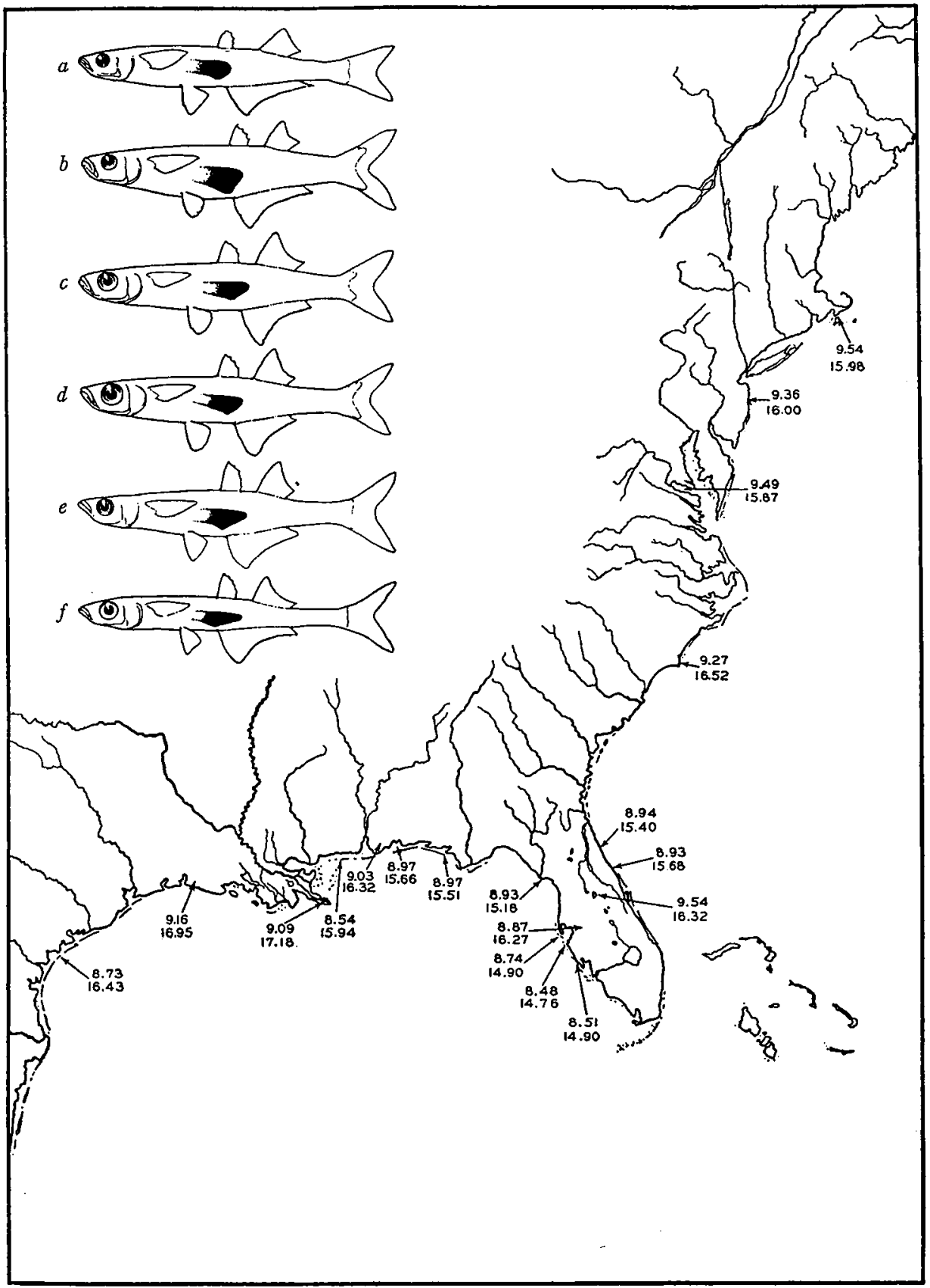

FIG. 1. Average second dorsal and anal ray counts in various samples of Menidia beryllina. Dorsal rays are given above, anal rays below for each sample. Insets: a, Massachusetts specimen of Menidia menidia; b, Florida specimen of $M$. menidia; c, Massachusetts specimen of $M$. beryllina; d, Florida spécimen of $M$. beryllina; $\mathrm{e}, M$. audens; $\mathrm{f}, M$. extensa. In the insets the position of the posterior extremity of the air bladder is indicated in black. Inset figures a-d redrawn from Kendall (1902). 
TABLE 1. Numbers of second dorsal and anal rays, and correlations between them, in various samples of Menidia beryllina

Starred samples are those not included in figure 1

\begin{tabular}{|c|c|c|c|c|c|c|}
\hline \multirow{2}{*}{ Loculity } & \multirow{2}{*}{$\begin{array}{l}\text { Number } \\
\text { of } \\
\text { specimens }\end{array}$} & \multicolumn{2}{|c|}{ Second dorsal rays } & \multicolumn{2}{|c|}{ Anal rays } & \multirow{2}{*}{$\begin{array}{c}\text { Coefficient } \\
\text { of } \\
\text { correlation }\end{array}$} \\
\hline & & Mean & $\begin{array}{l}\text { Standard } \\
\text { deviation }\end{array}$ & Mean & $\begin{array}{l}\text { Standard } \\
\text { deviation }\end{array}$ & \\
\hline Mass.: Barnstable Co. & 66 & 9.54 & \pm .6 .5 & 15.98 & \pm .89 & +.30 \\
\hline N. J.: Ocean Co. & 36 & 9.36 & \pm .67 & 16.00 & \pm .97 & +.55 \\
\hline Md.: Charles Co. & 61 & 9.49 & \pm .69 & 15.87 & \pm .97 & +.66 \\
\hline N. C.: New Hanover Co. & 71 & 9.27 & \pm .58 & 16.56 & \pm 1.02 & +.32 \\
\hline Fla.: St. Johns Co. & 35 & 8.94 & \pm .54 & 15.40 & \pm .59 & -.03 \\
\hline Fla.: Volusia Co. & 75 & 8.93 & \pm .61 & 15.68 & \pm .85 & +.61 \\
\hline Fla.: Lake Co. & 37 & 9.54 & \pm .60 & 16.32 & \pm .64 & +.39 \\
\hline Fla.: Charlotte Co. & 70 & 8.51 & \pm .65 & 14.90 & \pm 1.00 & +.50 \\
\hline Fla.: Manatee Co. & 50 & 8.48 & \pm .57 & 14.76 & \pm .73 & +.57 \\
\hline Fla.: Pinellas Co. & 113 & 8.74 & \pm .54 & 14.90 & \pm .91 & +.50 \\
\hline Fla.: Hillsborough Co. & 55 & 8.87 & \pm .66 & 16.27 & \pm .88 & +.37 \\
\hline Fla.: Levy Co. & 28 & 8.93 & \pm .65 & 15.18 & \pm 1.04 & +.71 \\
\hline Fla.: Bay Co. & 66 & 8.97 & \pm .58 & 15.51 & \pm .89 & +.38 \\
\hline Fla.: Santa Rosa Co. & 67 & 8.97 & \pm .46 & 15.66 & \pm .80 & +.66 \\
\hline Ala.: Baldwin Co. & 31 & 9.03 & \pm .60 & 16.32 & \pm .96 & +.38 \\
\hline Miss.: Jackson Co. & 52 & 8.54 & \pm .77 & 15.94 & \pm 1.01 & +.48 \\
\hline Miss.: Jackson Co.* & 65 & 8.80 & \pm .56 & 16.15 & \pm 1.10 & +.33 \\
\hline Miss.: Jackson Co.* & 50 & 9.00 & \pm .66 & 16.60 & $\begin{array}{l} \pm .98 \\
\pm .98\end{array}$ & +.52 \\
\hline La.: Orleans Parish* & 80 & 9.09 & \pm .57 & 17.11 & \pm 1.20 & +.40 \\
\hline La.: Plaquemines Parish & 54 & 9.09 & \pm .62 & 17.18 & \pm .94 & +.38 \\
\hline Ia.: Cameron Parish & 44 & 9.16 & \pm .56 & 16.95 & \pm 1.00 & +.38 \\
\hline Texas: Aransas Co. & 60 & 8.73 & \pm .66 & 16.43 & \pm .96 & +.37 \\
\hline
\end{tabular}

from south to north. However, the number of anal rays shows at best an erratic increase with latitude. For example, the average anal counts in many Gulf Coast samples (table 1 and fig. 1) is higher than that from Massachusetts. It is apparently: this geographic fluctuation in anal count. as opposed to a rather level gradient in dorsal count, which causes the lack of cor-

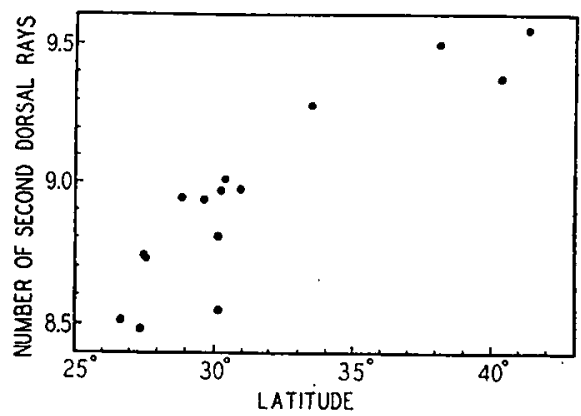

Fig. 2. Corrclation betwech mumber of second dorsal rays and latitude in marine samples of Menidia beryllina. relation between these two characters between populations.

In neither the dorsal nor the anal counts do the marine populations of $M$. beryllina show a continuous gradient from Texas to Massachusetts (table 1 and fig. 1). Rather, fish from both coasts of the Florida peninsula are set off by their minimal fin counts from the populations both to the northeast and to the west.

If only the marine populations of $M$. beryllina are considered, it might be possible on the basis of fin counts to divide the species into two or more, relatively homogeneous races. However, the situation is greatly complicated by the populations of this species which occur in fresh water. Such populations have been taken on Long Island, in the Potomac River, in North Cärolina (Kendall, 1902, pp. 259 and. 260), and from various localities in. Floricla and near the Gulf Coast. The fresh-water populations seem to differ from the salt-water fish in having a 
greater number of soft fin rays and scales, and, with some exceptions, in having a more elongate body. The relationship of these characters to decreasing salinity may be traced in series of adjacent populations (table 2). The two Florida series shown in this table consist of two populations each, one from fresh water and one marine. But the same gradient seems to apply in the three more or less marine populations from near Biloxi. Also, from the point of view of geographic proximity those samples beginning with that from the outer shore of Horn Island to the one

TABLE 2. Change in morphological characters from salt to fresh atater in Menidia beryllina and related fresh-zeater species

Means are given above, and number of specimens and standard error of the mean below in parentheses. Data for the starred item from Hubbs and Raney (19i6).

\begin{tabular}{|c|c|c|c|c|c|}
\hline Locality & Salinity & Anal rays & $\begin{array}{l}\text { Second } \\
\text { dorsal } \\
\text { rays }\end{array}$ & $\begin{array}{l}\text { Predorsal } \\
\text { scales }\end{array}$ & \begin{tabular}{|} 
Depth of body- \\
in per cent of \\
standard lengtl
\end{tabular} \\
\hline $\begin{array}{l}\qquad M . \text { beryllina } \\
\text { East-Central Florida } \\
\text { Volusia Co. }\end{array}$ & Salt? & $\begin{array}{c}15.68 \\
(75, \pm .10)\end{array}$ & $\begin{array}{c}8.93 \\
(75, \pm .07)\end{array}$ & $\begin{array}{c}14.2 \\
(10, \pm .25)\end{array}$ & $\begin{array}{c}20.8 \\
(10, \pm .19)\end{array}$ \\
\hline Lake Eustis, Lake Co. & Fresh & $\begin{array}{c}16.32 \\
(37, \pm .10)\end{array}$ & $\begin{array}{c}9.54 \\
(37, \pm .10)\end{array}$ & $\begin{array}{c}15.5 \\
(10, \pm .37)\end{array}$ & $\begin{array}{c}17.3 \\
(10, \pm .27)\end{array}$ \\
\hline $\begin{array}{l}\text { West Coast of Florida } \\
\text { Pinellas Co. }\end{array}$ & Salt & $\begin{array}{c}14.90 \\
(113, \pm .09)\end{array}$ & $\begin{array}{c}8.74 \\
(113, \pm .04)\end{array}$ & $\begin{array}{c}14.4 \\
(10, \pm .30)\end{array}$ & $\begin{array}{c}20.2 \\
(10, \pm .29)\end{array}$ \\
\hline Hillsborough Co. & Fresh? & $\begin{array}{c}16.27 \\
(55, \pm .12)\end{array}$ & $\begin{array}{c}8.87 \\
(55, \pm .09)\end{array}$ & $\begin{array}{c}15.4 \\
(10 . \pm .23)\end{array}$ & $\begin{array}{c}18.0 \\
(10, \pm .19)\end{array}$ \\
\hline $\begin{array}{l}\text { Biloxi, Mississippi region } \\
\text { Horn Island, seaward side }\end{array}$ & Salt & $\begin{array}{c}15.94 \\
(52, \pm .14)\end{array}$ & $\begin{array}{c}8.54 \\
(52, \pm .11)\end{array}$ & $\begin{array}{c}15.7 \\
(20, \pm .18)\end{array}$ & $\begin{array}{c}18.1 \\
(10, \pm .23)\end{array}$ \\
\hline Horn Island, landward side & Salt & $\begin{array}{c}16.15 \\
(65, \pm .14)\end{array}$ & $\begin{array}{c}8.80 \\
(65, \pm .17)\end{array}$ & $\begin{array}{c}15.0 \\
(20, \pm .16)\end{array}$ & $\begin{array}{c}17.8 \\
(10, \pm .16)\end{array}$ \\
\hline Biloxi Bay & Brackish? & $\begin{array}{c}16.60 \\
(50, \pm .14)\end{array}$ & $\begin{array}{c}9.00 \\
(50, \pm .09)\end{array}$ & $\begin{array}{c}15.8 \\
(20, \pm .12)\end{array}$ & $\begin{array}{c}18.5 \\
(10, \pm .34)\end{array}$ \\
\hline $\begin{array}{l}\text { Lower Mississippi valley } \\
\text { Lake Pontchartrain }\end{array}$ & Fresh? & $\begin{array}{c}17.11 \\
(80, \pm .14)\end{array}$ & $\begin{array}{c}9.09 \\
(80, \pm .06)\end{array}$ & $\begin{array}{c}15.8 \\
(20, \pm .20)\end{array}$ & $\begin{array}{c}17.8 \\
(10, \pm .24)\end{array}$ \\
\hline Mississippi delta & Fresh? & $\begin{array}{c}17.18 \\
(54, \pm .08)\end{array}$ & $\begin{array}{c}9.09 \\
(54, \pm .04)\end{array}$ & $\begin{array}{c}15.7 \\
(20, \pm .16)\end{array}$ & $(10, \stackrel{18.0}{ \pm .23})$ \\
\hline $\begin{array}{l}\text { M.audens } \\
\text { Ark., Chicot Co. }\end{array}$ & Fresh & $\begin{array}{c}18.24 \\
(53, \pm .11)\end{array}$ & $\begin{array}{c}9.37 \\
(53, \pm .08)\end{array}$ & $\begin{array}{c}19.4 \\
(20, \pm .32)\end{array}$ & $\begin{array}{c}16.0 \\
(10, \pm .25)\end{array}$ \\
\hline Tenn., Reelfoot Lake & Fresh & $\begin{array}{c}17.72 \\
(54, \pm .14)\end{array}$ & $\begin{array}{c}9.24 \\
(54, \pm .09)\end{array}$ & $\begin{array}{c}21.8 \\
(20, \pm .36)\end{array}$ & $\begin{array}{c}16.2 \\
(10, \pm .20)\end{array}$ \\
\hline $\begin{array}{l}\text { M. extensa } \\
\text { North Carolina } \\
\text { Lake Waccamaw* }\end{array}$ & Fresh & $\begin{array}{c}19.05 \\
(43,-,)\end{array}$ & $\begin{array}{c}9.4 \\
(43,-)\end{array}$ & $\begin{array}{c}22.0 \\
(18,-)\end{array}$ & $\begin{array}{c}13 \\
(19,-)\end{array}$ \\
\hline
\end{tabular}


from the Mississippi delta might be considered as one continuous series. Kendall (1902) found the same character gradient in the Potomac River. The conclusion that changes in these four characters are correlated with salinity seems inescapable.

Two fresh-water species of Menidia have been described, both of which seem distinct from one another and from $M$. beryllina (tables 2 and 3 ). M. audens is now distributed over a moderately large area of the lower Mississippi valley; it appears to be monophyletic. Structurally, though probably not phylogenetically, it is transitional between $M$. beryllina and $M$. crtensa (Hubbs and Raney, 1946). $M$. cxtensa is the most elongate species in the genus, with an increased number of fin rays, scales, and vertebrae. In all of these characters, except perhaps vertebrae, both $M$. audens and $M$. extensa appear to represent continuations of the salt-to-freshwater gradient indicated for $M$. beryllina.

In other fishes that have been studied there is usually an increase in meristic counts, not with decrease, but rather with increase in salinity. As a matter of fact, the typically marine species $M$. menidia shows such an increase in counts over $M$. beryllina, which is essentially a brackish- salt-water form (table 3). However, the cause of these high counts in $M$. menidia lies, I believe, in geography, as I shall point out below. However, because of the relatively large number of meristic elements in $M$. menidia the possibility exists that $M$. audens and $M$. cortensa are derivatives of this species rather than of $M$. beryllina. This seems unlikely for several reasons. Although $M$. menidia is found on the Carolina coast near $M$. extensa, it does not occur off the mouth of the Mississippi through which $M$. audens must have gone. M. menidia rarely occurs in fresh or even in brackish water. A chain of morphologic forms has been shown to link $M$. extensa with $M$. beryllina. In $M$. menidia the air bladder does not reach much beyond the anal origin whereas in $M$. beryllina, $M$. audens, and $M$. cxtensa respectively it extends backward beyond that point in increasing amounts (fig. 1, insets, and table $3^{3}$ ). Thus in the development of the air bladder $M$. beryllina is a logical intermediate between $M$. extensa and $M$. menidia.

The question remains then as to the

3 The increased length of the air bladder is reflected in the higher number of abdominal vertebrae (or vice versa) shown for $M$. audens and $M$. extensa in table 3 .

TABLE 3. Comparison of morphological characters in the four species of Menidia

Data for the starred items from Hubbs and Raney (1946). Means are given above, and number of specimens and range below in parentheses.

\begin{tabular}{|c|c|c|c|c|c|c|c|}
\hline $\begin{array}{l}\text { Species } \\
\text { and } \\
\text { locality }\end{array}$ & $\begin{array}{l}\text { Abdominal } \\
\text { vertebrae }\end{array}$ & $\begin{array}{c}\text { Caudal } \\
\text { vertebrae }\end{array}$ & $\begin{array}{c}\text { Total } \\
\text { vertebrae }\end{array}$ & $\begin{array}{l}\text { Number of } \\
\text { anal rays } \\
\text { with base } \\
\text { under air } \\
\text { bladder }\end{array}$ & Scales & Anal rays & $\begin{array}{l}\text { Snout-dorsal } \\
\text { distance } \\
\text { in per cent } \\
\text { of length }\end{array}$ \\
\hline $\begin{array}{l}\text { Menidia menidia } \\
\text { Massachusetts }\end{array}$ & $(8 ; 19.2$ & $\begin{array}{c}24.8 \\
(8 ; 24-26)\end{array}$ & $\begin{array}{c}44.0 \\
(8 ; 43-45)\end{array}$ & $\begin{array}{c}0.5 \\
(4 ; 0-1)\end{array}$ & $\begin{array}{c}45.8 \\
(6 ; 44-48)\end{array}$ & $\begin{array}{c}23.3 \\
(10 ; 21-25)\end{array}$ & $(10 ; 50.2-53.3)$ \\
\hline Florida & $\begin{array}{c}16.7 \\
(10 ; 15-19)\end{array}$ & $(10 ; 22-24)$ & $\begin{array}{c}39.4 \\
(10 ; 37-42)\end{array}$ & $\begin{array}{c}0.8 \\
(4 ; 0-2)\end{array}$ & $(9 ; 37-43)$ & $(10 ; 21-24)$ & $(10 ; 54.0-59.7)$ \\
\hline $\begin{array}{l}M \text { beryllina } \\
\text { Massachusetts }\end{array}$ & $(15 ; 17-19)$ & $\begin{array}{c}20.0 \\
(15 ; 19-21)\end{array}$ & $(15 ; 37-39)$ & $(4 ; 2-4)$ & $\begin{array}{c}39.2 \\
(10 ; 37-41)\end{array}$ & $\begin{array}{c}15.98 \\
(66 ; 14-19)\end{array}$ & $\begin{array}{c}51.6 \\
(10 ; 48.4-53.3)\end{array}$ \\
\hline Florida & $\begin{array}{c}18.1 \\
(10 ; 17-19)\end{array}$ & $\begin{array}{c}19.7 \\
(10 ; 19-21)\end{array}$ & $\begin{array}{c}37.8 \\
(10 ; 37-39)\end{array}$ & $\begin{array}{c}3.0 \\
(4 ; 3-3)\end{array}$ & $\begin{array}{c}39.9 \\
(9 ; 37-43)\end{array}$ & $\begin{array}{c}15.40 \\
(35 ; 14-16)\end{array}$ & $(10 ; 53.3$ \\
\hline $\begin{array}{l}M . \text { audens } \\
\text { Arkansas }\end{array}$ & $(10 ; 18-21)$ & $(10 ; 19-21)$ & $(10 ; 38-42)$ & $(10 ; 4-8)$ & $\begin{array}{c}40.9 * \\
(20 ; 39-44)\end{array}$ & $\begin{array}{c}18.15^{*} \\
(20 ; 16-20)\end{array}$ & $(10 ; 48.1-53.2)$ \\
\hline $\begin{array}{l}M \text {. exlensa } \\
\text { North Carolina }\end{array}$ & $\begin{array}{c}22.5 \\
(2 ; 22-23)\end{array}$ & $\begin{array}{c}20.5 \\
(2 ; 20-21)\end{array}$ & $\begin{array}{c}43.4^{*} \\
(13 ; 42-45)\end{array}$ & $\begin{array}{c}7.5 \\
(2 ; 7-8)\end{array}$ & $\begin{array}{c}46.4 * \\
(25 ; 44-50)\end{array}$ & $\begin{array}{c}19.05^{*} \\
(43 ; 16-21)\end{array}$ & $(10 ; 48.4-50.7)$ \\
\hline
\end{tabular}


relationship between $M$. beryllina and $M$. menidia. The latter species, as stated, shows an increase in meristic counts over $M$. beryllina (table 3 ). In the area between Mảssachusetts and Florida where the two species occur together, the direction of the morphological gradients is the same, but the degree to which these gradients are developed is very different. $M$. beryllina shows very little south-north increase, whereas $M$. menidia has developed into two subspecies well differentiated in the number of meristic elements (Kendall, 1902). Of these two subspecies, the southern in most respects resembles $M$. beryllina far more than the northern (table 3).

Finally as mentioned in the introduction, hybrids between $M$. menidia and $M$. beryllina have been found in northern Florida (Hubbs and Raney, 1946, p. 23). In the Michigan collections, hybrids between these two species were identified by Hubbs from two salt- or nearly salt-water localities in northeast Florida: Matanzas River, about $11 / 2$ miles south of Matanzas Inlet (called Matanzas Inlet population in table 4), St. Johns County; and Mosquito Lagoon, between Daytona Beach and Mosquito Inlet. (Both parent species were taken with the hybrids.) In order to verify the hybrid nature of these fishes, I have chosen four more or less independent characters which permit separation of the parent species in the area concerned. Means, their standard errors, and sample standard deviations for these characters are given in table 4 . The degree of intermediacy of the hybrids between the means of the parent populations is shown in fig. 3 .

One possibility in connection with these two populations is that such hybrids are fertile and, by backcrossing with one or both parents, contribute to the resemblance between the parent species in southern waters. The best check available on this point is a sample of pure $M$. menidia from the Matanzas River. This collection shows no significant differences from the Matanzas River Inlet population in which hybrids occur (table 4), indicating the conclusion that backcrossing has at least not effectively modified the $M$. menidia population in the Matanzas River Inlet.

On the basis of the foregoing data, certain conjectures concerning the processes of speciation in the genus Mcnidia may be permitted. In the first place, it seems fairly clear that $M$. andens has developed through invasion by $M$. beryllina stock of the Mississippi, and by subsequent isolation and differentiation in the lower Mis-

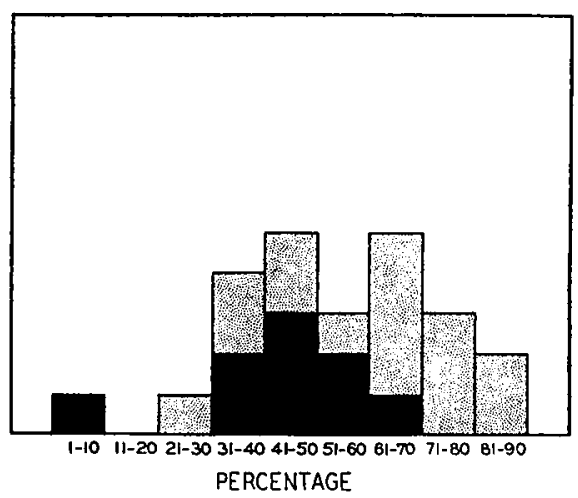

FIG. 3. Degrec of intermediacy between $h y-$ brids and their parent species, Menidia beryllina and M. menidia. Percentage intermediacy calculated according to the formula

$$
\frac{100 \text { (hybrid value }- \text { mean of } M \text {. beryllina) }}{\text { mean of } M . \text { menidia - mean of } M \text {. beryllina }}
$$

for each of the four characters shown in table 4 and the characters averaged. According to this method of calculation true $M$. beryllina would show a peak around 0 and true $M$. menidia a peak around 100 . The nine Matanzas Inlet hybrids are shown in black and the fifteen Mosquito Lagoon hybrids in the stippled area.

sissippi valley. M. extensa seems to have become isolated from the Atlantic coastal stock of $M$. beryllina when Lake Waccamaw became separated from the sea in late Pleistocene time (Hubbs and Raney, 1946).

The present relationship between $M$. beryllina and $M$. menidia appears to have had a more complex history. Both these species increase in the number of meristic counts to the northward; also, $M$. menidia has higher meristic counts than $M$. beryl- 
TABLE 4. Comparison of morphological characters between Menidia beryllina, M. menidia, and hybrids between the two

"P." equals the probability that the samples of $M$. menidia from Matanzas River and that from Matanzas Inlet were taken from the same population. Means are given above, and number of specimens, standard error of the mean, and range below in parentheses.

\begin{tabular}{|c|c|c|c|c|c|c|c|}
\hline Character & $\begin{array}{l}\text { Menidia } \\
\text { beryllina }\end{array}$ & $\begin{array}{c}\text { Difference } \\
\text { between } \\
\text { means of } \\
\text { hybrid } \\
\text { and of } M \text {. } \\
\text { beryllina }\end{array}$ & Hybrid & $\begin{array}{c}\text { Difference } \\
\text { between } \\
\text { means of } \\
\text { hybrid } \\
\text { and of } M . \\
\text { menilia }\end{array}$ & M. menidia & $\begin{array}{l}\text { Population of } \\
\text { pure } M . \\
\text { menidia } \\
\text { from the } \\
\text { Matanzas } \\
\text { River }\end{array}$ & P. \\
\hline $\begin{array}{l}\text { No. of specimens } \\
\text { Mosquito Lagoon } \\
\text { Matanzas Inlet }\end{array}$ & $\begin{array}{l}78 \\
34\end{array}$ & & $\begin{array}{r}15 \\
9\end{array}$ & & $\begin{array}{r}8 \\
99\end{array}$ & & \\
\hline $\begin{array}{l}\text { Inal rays } \\
\text { Mosquito Lagoon }\end{array}$ & $\begin{array}{c}15.68 \\
(75, \pm .04) \\
(13-19)\end{array}$ & 4.02 & $\begin{array}{c}19.70 \\
(15, \pm .24) \\
(18-22)\end{array}$ & 3.30 & $\begin{array}{c}23.00 \\
(8, \pm .42) \\
(22-25)\end{array}$ & & \\
\hline Matanzas Inlet & $\begin{array}{c}15.40 \\
(35, \pm .03) \\
(14-16)\end{array}$ & 3.16 & $\begin{array}{c}18.56 \\
(9, \pm .36) \\
(17-20)\end{array}$ & 3.44 & $\begin{array}{c}22.00 \\
(10, \pm .60) \\
(20-24)\end{array}$ & $\begin{array}{c}22.20 \\
(10 . \pm .42) \\
(21-24)\end{array}$ & .70 \\
\hline $\begin{array}{l}\text { Predorsal scales } \\
\text { Mosquito Lagoon }\end{array}$ & $\begin{array}{c}14.25 \\
(8, \pm .25) \\
(13-15)\end{array}$ & 2.95 & $\begin{array}{c}17.20 \\
(15, \pm .19) \\
(16-18)\end{array}$ & 1.18 & $\begin{array}{c}18.38 \\
(8, \pm .35) \\
(17-20)\end{array}$ & & \\
\hline Matanzas Inlet & $\begin{array}{c}14.30 \\
(10, \pm .23) \\
(1.3-15)\end{array}$ & 1.48 & $\begin{array}{c}15.78 \\
(9, \pm .27) \\
(11-17)\end{array}$ & 1.82 & $\begin{array}{c}17.60 \\
(10, \pm .24) \\
(17-19)\end{array}$ & $\begin{array}{c}17.30 \\
(10, \pm .37) \\
(16-19)\end{array}$ & .60 \\
\hline $\begin{array}{l}\text { Preventral Scales } \\
\text { Mosquito Lagoon }\end{array}$ & $\begin{array}{c}14.25 \\
(8, \pm .30) \\
(13-15)\end{array}$ & 1.48 & $\begin{array}{c}15.73 \\
(15, \pm .24) \\
(13-17)\end{array}$ & .77 & $\begin{array}{c}16.50 \\
(8, \pm .50) \\
(15-19)\end{array}$ & & \\
\hline Matanzas Inlet & $\begin{array}{c}12.80 \\
(10, \pm .33) \\
(11-14)\end{array}$ & 1.31 & $\begin{array}{l}14.11 \\
(9, \pm .35) \\
(13-16)\end{array}$ & 2.09 & $\begin{array}{c}16.20 \\
(10, \pm .44) \\
(14-18)\end{array}$ & $\begin{array}{c}16.20 \\
(10, \pm .42) \\
(14-19)\end{array}$ & 1.00 \\
\hline $\begin{array}{l}\text { Snout-dorsal (in per } \\
\text { cent of length) } \\
\text { Mosquito Lagoon }\end{array}$ & $\begin{array}{c}51.89 \\
(8, \pm .44) \\
(49.7-53.5)\end{array}$ & 3.49 & $\begin{array}{c}55.38 \\
(15, \pm .26) \\
(53.2-57.1)\end{array}$ & 2.61 & $\begin{array}{c}57.99 \\
(8, \pm .34) \\
(56.8-59.7)\end{array}$ & & \\
\hline Matanzas Inlet & $\begin{array}{c}53.27 \\
(10, \pm .24) \\
(52.3-54.8)\end{array}$ & 1.75 & $\begin{array}{c}55.02 \\
(9, \pm .47) \\
(52.2-57.3)\end{array}$ & 2.24 & $\begin{array}{c}57.26 \\
(10, \pm .58) \\
(54.0-59.7)\end{array}$ & $\begin{array}{c}56.60 \\
(10, \pm .25) \\
(55.5-57.6)\end{array}$ & .29 \\
\hline
\end{tabular}

lina. Therefore, it seems that an original beryllina-menidia stock may have split into a northern form which is now $M$. menidia and a southern form, now $M$. beryllina. This suggestion is strengthened by the fact that now $M$. beryllina ranges farther to the south (to which it has presumably become better adapted) than $M$. menidia, whereas the latter extends farther to the north.

It may be further speculated that this split in the beryllina-menidia stock was 
caused by the rise of the Florida perinsula from the sea, leaving the ancestors of $M$. beryllina in the Gulf of Mexico and those of $M$. menidia on the Atlantic Coast. Under this hypothesis $M$. beryllina would have since spread up the Atlantic Coast. That $M$. menidia is the older form of the two along this coast is suggested by the fact that it has formed two well-differentiated subspecies there, whereas $M$. beryllina has not. However, if $M$. beryllina is postulated as the ancestor of $M$. extcnsa, $M$. beryllina must have been along the Carolina coast in the Pleistocene.

If the two species have lived together on the Atlantic Coast since the Pleistocene, the question arises, why do they now hybridize in Florida? This question does not reflect adversely upon the hypothesis set forth, since it would have come up in connection with any hypothesis whatever. Perhaps the best answer is that $M$. menidia is now in the process of extending its range southward, and that its southern outposts undertake spawning under conditions which they do not encounter in their normal range. These conditions in Florida might include such factors as overlap in spawning season or habitat with $M$. beryllina, the absence of sufficient numbers of $M$. monidia to undertake spawning alone, etc.

I wish to thank R. M. Bailey and E. T. Hooper of the Museum of Zoology, University of Michigan, for reading this paper and for suggestions concerning the hypothetical treatment of the processes of speciation in the genus. All specimens reported on in this paper are in the University of Michigan collections.

\section{SUMMARY}

The phylogeny of the genus Menidia was approached through a study of morphological characters, ecology, and geographical distribution of the four species now attributed to the genus. The two fresh-water species, audens (Lower Mississippi Valley) and extensa (Lake Waccamaw, North Carolina), appear to be recent (Pleistocene or later) derivatives of the stock of boryllina, a species now abundant in coastal salt and fresh water along the Atlantic Coast from Vera Cruz. Mexico to Massachusetts. The two coastal species, beryllina and monidia, seem to have evolved from a single ancestral form through geographical isolation and differentiation in a northern group of populations, now represented by monidia, and a Gulf of Mexico population, now represented by beryllina. There is some hybridization between the species monidia and bcryllina in northern Florida, and a preliminary analysis indicates that this hybridization has not altered the phenotypic characters of populations of the parent species menidia from the same area.

\section{Literature Crted}

Hubss, C. L., and E. C. Raner. 1946. Endemic fish fauna of Lake Waccamaw, North Carolina. Misc. Publ. Mus. Zool. Univ. Michigan, No. 65, 1-30. Pl. I.

Kendal, W. C. 1902. Notes on the silversides of the genus Menidia of the East Coast of the United States, with descriptions of two new subspecies. Rept. U. S. Comm. Fish and Fisheries for 1901, 241-267.

Schultz, L. P. 1948. A revision of six subfamilies of atherine fishes, with descriptions of new genera and species. Proc. U. S. Nat. Mus., 98: $1-48$. Pls. I and II. 